\title{
Serum homocysteine in pre-eclampsia and eclampsia
}

\author{
Md. Mozammel Hoque ${ }^{1}$, Tania Bulbul ${ }^{1}$, Monzarin Mahal $^{2}$, Nur-A-Farzana Islam ${ }^{3}$ \\ and Munira Ferdausi ${ }^{4}$ \\ ${ }^{1}$ Department of Biochemistry, Bangabandhu Sheikh Mujib Medical University, Shahbag, Dhaka; \\ ${ }^{2}$ Department of Biochemistry, Dhaka Medical College, Dhaka; ${ }^{3}$ Department of Biochemistry, North East \\ Medical College, Sylhet; ${ }^{4}$ Department of Obstetrics and Gynecology, Rajshahi Medical College, \\ Rajshahi, Bangladesh.e-mail:m_mhoque@yahoo.com
}

\begin{abstract}
Pre-eclampsia and eclampsia are common obstetrical problem causing adverse effects on pregnancy outcome. Large bodies of evidences suggest that hyperhomocysteinemia is a causal factor of pre-eclampsia/eclampsia. This study designed to explore the association between hyperhomocysteinemia and pre-eclampsia/eclampsia, the knowledge of which expected to be used for prevention of pre-eclampsia and eclampsia. In a case-control study serum homocysteine was measured in 136 controls (healthy pregnant), 84 pre-eclamptic and 120 eclamptic pregnant women. Serum homocysteine in patients with pre-eclampsia $(9.54 \pm 3.21 \mu \mathrm{mol} / \mathrm{L})$ and eclampsia $(10.57 \pm 3.39 \mu \mathrm{mol} / \mathrm{L})$ found to be significantly increased compared to controls $(6.86 \pm 2.47$ $\mu \mathrm{mol} / \mathrm{L})(\mathrm{p}<0.001)$. Between pre-eclampsia and eclampsia, homocysteine found to be raised more in eclampsia compared to pre-eclampsia $(\mathrm{p}<0.03)$. In conclusion, hyperhomocysteinemia is associated with pre-eclampsia as well as eclampsia, but in eclampsia the severity of homocysteine elevation is more compared to that in pre-eclampsia.
\end{abstract}

\section{Introduction}

Pre-eclampsia/eclampsia is the most common serious medical disorder of human pregnancy, which complicates approximately $5-7 \%$ of pregnancy $^{1,}{ }^{2}$. Pre-eclampsia is a pregnancy specific, multisystem disorder that is characterized by the development of hypertension and proteinuria after 20 weeks of gestation ${ }^{2}$. Edema is often seen but is not essential to make the diagnosis. If seizures occur as a complication of pre-eclampsia, the term eclampsia is used ${ }^{3}$. In addition to elevated blood pressure and proteinuria, impaired liver function, increased serum uric acid, decreased platelet count, and symptoms and signs, such as headache, visual disturbances, epigastric pain and pulmonary edema are considered particularly ominous ${ }^{4}$. Hypertension was reported to account for $15 \%$ of all antenatal hospitalizations for pregnancy complications ${ }^{5}$. Women who develop pre-eclampsia or eclampsia during pregnancy are at an increased risk of abruptio placentae, acute renal failure, cerebrovascular and cardiovascular complications, and maternal death ${ }^{6,7}$.
Pre-eclampsia is still regarded as "a disease of theories" and its etiology has remained poorly understood $^{8}$. Although the specific cause remain unknown, endothelial dysfunction has been considered central in the pathophysiology of preeclampsia ${ }^{9}$.

Homocysteine is sulfur containing essential amino acid primarily derived from demethylation of dietary methionine required for the growth of cells and tissues in the human body ${ }^{10}$. In hyperhomocysteinemia, homocysteine undergoes auto-oxidation to produce reactive oxygen species (ROS), which inactivates nitric oxide and thrombomodulin leading to endothelial damage and endothelial dysfunction. Homocysteine also interferes with fibrinolytic system adding to the pathophysiology of eclampsia and pre-eclampsia ${ }^{11}$.

In normal pregnancy serum homocysteine is normally decreased, due either to hemodilution incident to pregnancy or the relative deficiency during pregnancy ${ }^{12}$. Maternal hyperhomocysteinemia has been associated with a number of pregnancy associated diseases such as pre- 
eclampsia, placental abruption, recurrent pregnancy loss and neural tube defect in newborn ${ }^{13-17}$.

Bangladesh is a densely populated country. Like many other developing countries, we are facing various health related problems including high maternal mortality, which is 3.15 per 1,000 women $^{18}$. The incidence of such mortality in developed countries has been reduced to $0.2-0.5 \%$ of all deliveries with a case fatality of $2 \%{ }^{19}$. In Bangladesh, the incidence of pre-eclampsia and eclampsia are alarmingly high and about $16 \%$ of maternal deaths are associated with $\mathrm{it}^{20}$. Intrauterine growth retardation, pre-term delivery, low birth weight, fetal death and neonatal death due to complication of pre-term delivery are common perinatal outcomes associated with pre-eclampsia ${ }^{21}$.

To decrease pre-eclampsia and eclampsia related mortality, appropriate prenatal care must be available to all women. Early detection, careful monitoring and treatment of pre-eclampsia are crucial in preventing mortality related to this $\operatorname{disorder}^{22,23}$.

It has been proposed that hyperhomocysteinemia may be associated with pre-eclampsia as the homocysteine mediated vascular changes are similar to those associated with pre-eclampsia ${ }^{24,25}$. With respect to hyperhomocysteinemia several studies found to be done in pre-eclampsia but very few studies so far have been done to explore the association between hyperhomocysteinemia and eclampsia. With the intention to reduce the maternal mortality by preventing preeclampsia/eclampsia through serial monitoring of serum homocysteine as a part of antenatal check-up in a developing country like Bangladesh, we have planned this study to explore the association between hyperhomocysteinemia and pre-eclampsia /eclampsia.

\section{Materials and Methods}

A case control study was conducted at the Department of Biochemistry, Bangabandhu Sheikh Mujib Medical University (BSMMU), Dhaka, from January 2005 to December 2006. One hundred thirty six normotensive healthy pregnant women as control (Group I), 84 pregnant women with preeclampsia (Group II) and 120 pregnant women with eclampsia (Group III) were included in the study. Subjects were selected from the Department of Obstetrics and Gynecology, BSMMU, Dhaka Medical College and Sir Salimullah Medical College. Study subjects of each group were apparently matched with respect to maternal age, gestational age and BMI. All study subjects were enrolled in the study after having their deliberate informed written consent. Ethical clearance was taken from the Ethical Committee of BSMMU and other concerned departments.

Pre-eclampsia was diagnosed by a) pregnancy with gestational age $>20$ weeks, b) systolic blood pressure $\geq 140 \mathrm{mmHg}$, c) diastolic blood pressure $\geq 90 \mathrm{~mm} \mathrm{Hg}$ recorded on two separate occasions 6 hours apart and d) 24-hour urinary protein $\geq 300$ mg. Patients developing convulsion or coma superimposed on pre-eclampsia were regarded as eclampsia $^{26}$.

Pregnant women with possible confounding variables like pre-existing hypertension, cardiovascular disease, renal disease, diabetes mellitus or other endocrinopathies and antifolate drug (antiepileptic, methotrexate) therapy were excluded from the study.

Blood samples were collected with all aseptic precautions from all study subjects after an overnight fasting. Samples were centrifuged and serum was separated and stored at $-35^{\circ} \mathrm{C}$ until analysis. Serum homosysteine level was measured by fluorescence polarization immunoassay (FPIA) run on Abbott's AxSYM platform ${ }^{27}$.

Statistical analysis was performed using SPSS (version 12.00 for windows, software). To find out the statistical significance one way ANOVA test was done among groups and then Mann Whitney's U-test was done between the groups. $\mathrm{P}<0.05$ was considered statistically significant.

\section{Results}

Study revealed the mean serum homocysteine concentration in pre-eclampsia to be $9.54 \pm 3.21$ $\mu \mathrm{mol} / \mathrm{L}$ with the median value of $9.04 \mu \mathrm{mol} / \mathrm{L}$ and that in eclampsia to be $10.57 \pm 3.39 \mu \mathrm{mol} / \mathrm{L}$ with the median value of $10.07 \mu \mathrm{mol} / \mathrm{L}$. In control subjects mean homocysteine concentration was $6.86 \pm 2.47 \mu \mathrm{mol} / \mathrm{L}$ with the median value of 6.28 $\mu \mathrm{mol} / \mathrm{L}$.

Table I: Grouping of study subjects with age distribution and BMI

\begin{tabular}{lccc}
\hline & $\begin{array}{c}\text { Normal pregnancy } \\
(\mathrm{n}=136)\end{array}$ & $\begin{array}{c}\text { Pre-eclampsia } \\
(\mathrm{n}=84)\end{array}$ & $\begin{array}{c}\text { Eclampsia } \\
(\mathrm{n}=120)\end{array}$ \\
\hline Age (years) & $25.84 \pm 5.43$ & $24.00 \pm 4.14$ & $25.83 \pm 5.69$ \\
Gestational & $30.80 \pm 4.03$ & $28.70 \pm 4.05$ & $31.70 \pm 3.59$ \\
age (weeks) & & & \\
BMI & $21.7 \pm 1.7$ & $24.3 \pm 1.2$ & $24.6 \pm 2.3$ \\
\hline
\end{tabular}


Mann-Whitney $U$ test shows that serum homocysteine concentration significantly increased in both pre-eclampsia and eclampsia compared to control. Homocysteine also found to be significantly raised in eclampsia compared to preeclampsia $(\mathrm{p}<0.03)$.

Table II: Comparison of serum homocysteine concentration among different groups of study subjects

\begin{tabular}{|c|c|c|c|}
\hline & $\begin{array}{l}\text { Homocysteine } \\
(\mu \mathrm{mol} / \mathrm{L})\end{array}$ & F value* & $P$ value \\
\hline Normal pregnancy & $6.86 \pm 2.47$ & & \\
\hline Pre-eclampsia & $9.54 \pm 3.21$ & 51.423 & 0.000 \\
\hline \multirow[t]{2}{*}{ Eclampsia } & $10.57 \pm 3.39$ & & \\
\hline & $\begin{array}{l}\text { Homocysteine } \\
\text { (median) } \mu \mathrm{mol} / \mathrm{L}\end{array}$ & U value** & $\mathrm{P}$ value \\
\hline $\begin{array}{l}\text { Control vs. pre- } \\
\text { eclampsia }\end{array}$ & 6.28 vs. 9.04 & 2762 & 0.000 \\
\hline $\begin{array}{l}\text { Control vs. } \\
\text { eclampsia }\end{array}$ & 6.28 vs. 10.07 & 2977 & 0.000 \\
\hline $\begin{array}{l}\text { Pre-eclampsia vs. } \\
\text { eclampsia }\end{array}$ & 9.04 vs. 10.07 & 4132 & 0.029 \\
\hline
\end{tabular}

\section{Discussion}

Serum homocysteine concentration in preeclampsia has been reported in a number of studies but the study of homocysteine in eclampsia is scanty. In line with this study, many studies abroad have demonstrated the relationship between hyperhomocysteinemia and pre-eclampsia ${ }^{25,28,29}$ while others have refuted an association ${ }^{11}$. This relationship has been shown in early pregnancy ${ }^{30}$, in second trimester ${ }^{31}$, and in the third trimester of pregnancy $^{32}$. Cotter et $\mathrm{al}^{30}$ in their study concluded that in early pregnancy increased homocysteine may be associated with a 4-fold increased risk for development of non severe pre-eclampsia. On the other hand, it has been suggested that mid-trimester plasma homocysteine concentrations in asymptomatic women are not predictive of the subsequent development of pre-eclampsia ${ }^{33}$.

In consistent with our findings Gurbuz et al. ${ }^{29}$ also found homocysteine concentration to be raised in pre-eclampsia and the level in eclampsia being higher than that in severe pre-eclampsia. So, serum homocysteine concentration tends to be positively correlated with the degree of severity of disease. However some study showed no significant difference of homocysteine concentration between pre-eclampsia and eclampsia ${ }^{27,28,34}$, which might be due to smaller sample size.

Folate, vitamin $\mathrm{B}_{12}$, vitamin $\mathrm{B}_{6}$, and riboflavin are involved in the metabolism of homocysteine. ${ }^{35}$
Elevated homocysteine is a marker of low Bvitamin status or decreased methylation capacity of cells $^{36,37}$. So, vitamin B supplementation could have a role in preventing the elevation of homocysteine in pregnant women ${ }^{35}$.

This study concludes that elevated homocysteine level is associated with pre-eclampsia and eclampsia and the higher homocysteine concentration in eclampsia compared to preeclampsia indicates its subtle association with the severity of disorder as well. So, maternal hyperhomocysteinemia seems to have causal role in the etiopathogenesis of pre-eclampsia /eclampsia. It needs more study to delineate the relationship between the serum homocysteine concentration and the severity of pre-eclampsia and eclampsia.

This study suggests the measurement of serum homocysteine in all pregnant women as a part of routine antenatal check-up and thereby monitoring and management of hyperhomocysteinemia in antenatal period taking into account the B-vitamin supplementation might help substantially to reduce the adverse pregnancy outcome.

\section{Authors' contribution}

MMH: Planning, research tool development, supervision and data analysis

TB: Data analysis and manuscript writing

MM: Field work and data collection

NAFI: Field work and data collection

MF: Field work and data collection

\section{References}

1. Roberts JM, Redman CWG. Pre-eclampsia: More than pregnancy induced hypertension. Lancet 1993; 341: 1447-51.

2. Witlin AG, Sibai BM. Magnesium sulfate therapy in pre-eclampsia and eclampsia. Obstet Gynecol. 1998; 92: 883-89.

3. Centers for Disease Control and Prevention: Maternal mortality: United States, 1982-1996. MMWR Morb Mortal Wkly Rep. 1998; 171: 705-07.

4. Gifford R, August P, Chesley L. National high blood pressure education program working group report on high pressure in pregnancy. Am J Obstet Gynecol. 1990; 163: 1689-1712.

5. Scott CL, Chavez GF, Atrash HK, Taylor DJ, Shah RS, Rowley D. Hospitalization for severe complications of pregnancy, 1987-1992. Obstet Gynecol. 1997; 90: 22529. 
6. Cunningham FG, MacDonald PC, Gant NF, Leveno KJ, Gilstrap LC. Williams obstetrics. $20^{\text {th }}$ ed. Cunnecticut; Appletion and Lange, 1997.

7. Abdella TN, Sibai BM, Hays JM, Anderson GD. Relationship of hypertensive disease to abruption placentae. Obstet Gynecol. 1984; 63: 365-70.

8. Dekker G, Sibai B. Etiology and pathogenesis of preeclampsia: Current concepts. Am J Obstet Gynecol. 1998; 179: 1359-75.

9. Roberts J, Taylor R, Musci T, Rodgers G, Hubel C, McLaughlin M. Preeclampsia: An endothelial call disorder. Am J Obstet Gynecol. 1989; 161: 1200-04.

10. Refsum H, Ueland PM, Nygard O, Vollset SE Homocysteine and cardiovascular disease. Ann Rev Med. 1998; 49: 31-62.

11. Sydow K, Schwedhelm E, Arakawa N, Bode-Boger SM, Tsikas D, Horning B, Frohilch JC, Boger RH. ADMA and oxidative stress are responsible for endothelial dysfunction in hyperhomocysteinemia: Effects of L-arginine and B vitamins. Cardiovasc Res. 2003; 57: 244-58.

12. Walker MC, Smith GN, Perkins SL, Keely EJ, Garner PR. Changes in homocysteine level in normal pregnancy. Am J Obstet Gynecol. 1999; 180: 660-64.

13. Ray JG, Laskin CA. Folic acid and homocysteine metabolic defects and the risk of placental abruption, pre-eclampsia and spontaneous pregnancy loss: A systemic review. Placenta 1999; 20: 519-29.

14. Dekker G, de Varies J, Doelitzsch P. Underlying disorders associated with severe early-onset preeclampsia. Am J Obstet Gynecol. 1995; 173: 104248.

15. Goddijin-Wessel T, Wouters M, vd Molen E. Hyperhomocysteinemia: A risk factor for placental abruption or infarctio. Eur J Obstet Gynecol Reprod Biol. 1996; 66: 23-29.

16. Woters M, Boers G, Trijbels F. Hyperhomocysteinemia: A risk factor in women with unexplained recurrent early pregnancy loss. Fetril Steril. 1993; 60: 820-25.

17. Powers R, Evans R, Majors A. Plasma homocysteine concentration is increased in pre-eclampsia and associated with evidence of endothelial activation. Am J Obstet Gynecol. 1998; 179: 1605-11.

18. Bangladesh Bureau of statistics. Ministry of Planning. 2004, National census 2002

19. Mabie WC, Sibai BM. Hypertensive states of pregnancy. In: Current obstetric \& gynecologic diagnosis \& treatment. DeCherney AH, Pernoll ML (eds). $8^{\text {th }}$ ed. USA, Appleton and Lange, 1994, p 388.

20. Rashid KM, Rahman M, Hyder S. Textbook of community medicine and public health. $4^{\text {th }}$ ed. Dhaka, RHM publishers, 2004.
21. Ware-Jauegi S, Sanchez SE, Zhang C, Laraburre G, King IB. Williams MA. Plasma lipid concentrations in pre-eclamptic and normotensive Pruvian women. Int J Obstet Gynecol. 1999; 67: 147-55.

22. Mackey AP, Berg CJ, Atrash HK. Pregnancy related mortality from pre-eclampsia and eclampsia. Obstet Gynecol. 2001; 197: 533-38.

23. Dekker G, Sibai B. Primary, secondary, and tertiary prevention of pre-eclampsia. Lancet 2001; 105: 117784.

24. Rajkovic A, Catalano PM, Malinow MR. Elevated homocysteine level with pre-eclampsia. Obstet Gynecol. 1997; 90: 168-71.

25. Zeeman GG, Alexander JM, McIntire DD, Devaraj S, Leveno KJ. Homocysteine plasma concentration levels for the prediction of pre-eclampsia in women with chronic hypertension. Am J Obstet Gynecol. 2003; 189: 574-76.

26. Ingec $\mathrm{M}$, Borekci $\mathrm{B}$, Kadanali $\mathrm{S}$. Elevated plasma homocysteine concentrations in severe pre-eclampsia and eclampsia. Tohoku J Exp Med. 2005; 206: 225-31.

27. Pernet P, Lasnier E, Vaubourdolle M: Evaluation of the AxSYM homocysteine assay and comparison with the IMX homocysteine assay. Clin Chem. 2000; 46: 144041.

28. Rajkovic A, Mahomed K, Malinow MR, Sorenson TK, Woelk GB, Williams MA. Plasma homocysteine concentration in eclamptic and pre-eclamptic African women postpartum. Obstet Gynecol. 1999; 94: 355-60.

29. Gurbuz A, Karateke A, Mengulluoglu M. Elevated plasma homocys teine levels in preeclampsia and eclampsia. Int J Gynecol Obstet. 2004; 87: 165-66.

30. Cotter AM, Molloy AM, Scott JM, Daly SF. Elevated plasma homocysteine in early pregnancy: A risk factor for the development of severe preeclampsia. Am J Obstet Gynecol. 2001; 185: 781-85.

31. Sorensen TK, Malinow MR, Williams MA, King IB, Luthy DA. Elevated second trimester serum homocysteine level and subsequent risk for preeclampsia. Gynecol Obstet Invest. 1999; 48: 98-103.

32. Sanchez SE, Zhang C, Rene, Malinow M, WareJauregui S, Laraburre G, Williams MA. Plasma folate, vitamin $\mathrm{B} 12$, and homocysteine concentration in preeclamptic and normotensive Peruvian women. Am J Epidemiol. 2001; 153: 474-80.

33. Heitala R, Turpeinen U, Laatikainen T. Serum homocysteine in 16 weeks and subsequent preeclampsia. Obstet Gynecol. 2001; 97: 527-29.

34. Middledrop S, van de Poel MH, Bank I, Hamulyak K, Libourel EJ, Koopman MM, Prins MH, van der Meer J, Buller HR. Unselected women with elevated levels of factor VIIIC or homocysteine are not at increased risk for obstetric complications. Thromb Haemost. 2004; 92: 787-90. 
35. Strain JJ, Dowey L, Ward M, Pentieva K, McNulty H. B-vitamins, homocysteine metabolism and CVD. Nutrition Society 2004; 63: 597-603.

36. Castro R, Rivera I, Struys EA, Jansen EEW, Ravasco P, Camilo ME, Blom HJ, Jakobs C, de Almeida IT. Increased homocysteine and S-adenosylhomocysteine concentrations and DNA hypomethylation in vascular disease. Clin Chem. 2003; 49: 1292-96.

37. Patrick TE, Powers RW, Daftary AR, Ness RB, Roberts JM. Homocysteine and folic acid are inversely related in black women in pre-eclampsia. Hypertension 2004; 43: 1279. 